\title{
Adoption of Mobile Marketing in the Telecommunication Industry of Tanzania: The Effects of Perceived Usefulness, Ease of Use, and Customer's Knowledge
}

\author{
Felix Joseph Chille \\ College of Business Education, Dar es Salaam, Tanzania \\ France Aloyce Shayo \\ Open University of Tanzania, Dar es Salaam, Tanzania \\ Nasra Shokat Kara \\ Open University of Tanzania, Dar es Salaam, Tanzania
}

Doi:10.19044/esj.2021.v17n12p160

Submitted: 25 January 2021

Accepted: 20 April 2021

Published: 30 April 2021

\author{
Copyright 2021 Author(s) \\ Under Creative Commons BY-NC-ND \\ 4.0 OPEN \\ ACCESS
}

Cite As:

Chille, JF., Shayo, AF., and Kara, SN. (2021). Adoption of Mobile Marketing in the Telecommunication Industry of Tanzania: The Effects of Perceived Usefulness, Ease of Use, and Customer's Knowledge. European Scientific Journal, ESJ, 17(12),160. https://doi.org/10.19044/esj.2021.v17n12p160

\begin{abstract}
This paper focuses on identifying the factors affecting customer's adoption of mobile marketing by examining the effects of perceived usefulness, perceived ease of use, and perceived customer's knowledge in the telecommunications industry of Tanzania. The study extended the Technology Acceptance Model (TAM), with Diffusion of Innovation Theory (DOI), in predicting the customer's mobile marketing adoption. Survey strategy was employed in data collection by administering the structured questionnaires and collected data using multi stage sampling on 406 respondents in Dar es Salaam. After then, it was analyzed using factor
\end{abstract}


analysis, correlation analysis, and multiple linear regression analysis. Findings indicated that perceived usefulness, perceived ease of use, and perceived customer knowledge have significant and positive influence on the adoption of mobile marketing in the telecommunication industry in Tanzania. The study contributes to telecommunication practitioners with the integrated theoretical framework, which suggest that telecommunication practitioners need to develop mobile platforms that are easy to use, useful in solving customers' problems and in designing products whose benefits are easily understood by customers. Through holistic mobile marketing approach, this study makes parsimonious contribution to knowledge by using few variables in predicting the customer's adoption of mobile marketing in Telecommunication industry in Tanzania.

Keywords: Mobile Marketing, Perceived usefulness, Perceived ease of use, perceived customer knowledge, Technology Acceptance Model. 


\subsection{Introduction}

The increased adoption of mobile marketing has boosted business productivity worldwide (Hall, 2018). This has been facilitated by the use of mobile marketing applications in undertaking marketing activities. Currently, mobile marketing platform is among the marketing channels of distribution for enhancing business interactions and communication between customers and marketers (Asa \& Uwem, 2017; Barutcu et al., 2017). The emergence of advanced mobile technology has facilitated the increase in business opportunities, hence assisting marketers and customers' linkage without the consideration of time and place (Eze et al., 2020).

According to Mobile Marketing Association (MMA, 2009) definition, mobile marketing is the marketing activities and processes facilitated by mobile technologies through wireless communication for creating, communicating, and delivering customers' and stakeholders' value through mobile devices online (Ström et al., 2014).

There is a growing body of knowledge concerning mobile marketing adoption in developed countries (Mansour, 2016), but the adoption is still little in developing countries (Lamptey, 2017). Among the various models that has been applied is the Technology Acceptance Model (TAM) (Ajibade, 2018 ; Davis et al., 1989), which indicated much adoption of mobile marketing in developed countries (Lamptey, 2018).

Lately, the advancement of mobile marketing in Tanzania is gradually being evidenced by the presence of technological development that facilitates vast online transaction services (URT, 2018). If well utilized, these offer compelling opportunities to a number of consumers to interact through mobile technology in order to increase their marketing and business capabilities (Jauhari \& Dutta, 2010). Despite that, the number of customers involved in mobile marketing in Tanzania is still low in comparison to other African countries (Chille et al., 2021; Malamsha, 2019; Masamila, 2014; Mtebe \& Raisamo, 2014; Mwantimwa, 2019; Wilson \& Mbamba, 2017). However, there are paucity in studies concerning mobile marketing in Tanzania (Lwoga \& Lwoga, 2017; Malamsha, 2019). It is evident that most of the past studies in Tanzania were based on mobile payment and mobile banking as part of mobile marketing. However, there are scantily any studies that have focused on mobile marketing in terms of perceived usefulness (PU), perceived ease of use (PEOU), and perceived customer knowledge (PCK). This is based on the holistic way of mobile marketing as per its definition and scope as described by the Mobile Marketing Association (MMA, 2009; Lwoga \& Lwoga, 2017; Malamsha, 2019), compared to the studies done in developed countries (Lamptey, 2018). 
Past studies have indicated that using TAM alone showed that actual behavior and behavioral intention could be different phenomenon to the adopters, and this is the setback in using the TAM model alone (Ajibade, 2018; Keung et al., 2004). In their study, Rodgers (2003) and Saaksjarvi (2003) indicated that, in order for individuals to adopt the new technology, there is a need for the customers' understanding of the products and services through customers' knowledge, and this knowledge is transmitted gradually as explained on Diffusion of Innovation Theory (DOI). With those reasons, this study has combined the Technology Acceptance Model (TAM) to include the Diffusion of Innovation Theory (DOI) by adding a construct of perceived customer knowledge. Thus, this is in studying the factors that influence the adoption of mobile marketing in telecommunication industry in Tanzania and testing it.

Due to paucity in studies guided by Technology Acceptance Model (TAM) on the effects of PU, PEOU in Tanzania, especially in the telecommunication industry, compared with developed countries (Lamptey, 2018), this study attempts to design and develop "Integrative Adoption Model" by combining the Technology Acceptance Model (TAM) and Diffusion of Innovation Theory (DOI) for localized Mobile Marketing Technologies (MMT) that ties with customer involvement in driving business transaction. This is done by assessing the effects of Perceived Usefulness (PU) and Perceived Ease of Use (PEOU) as the major constructs of TAM and extending the Technology Acceptance Model (TAM) with the construct of Perceived Customer Knowledge (PCK) which is guided by the Diffusion of Innovation Theory (DOI), in order to identify the factors that can influence customers' mobile marketing adoption in the telecommunication industry in Tanzania.

Basically, the research study responds to the insufficient contextualized adoption models, and the new ways of interacting with advanced technologies that offer a wide-range of online marketing services. As such, the model will entrench customers to adopt the cutting edge of mobile marketing technology designing, development, and implementation process throughout the product or service cycle.

Technology Acceptance Model (TAM) has been used in various studies in Tanzania for assessing the effects of user acceptance of mobile payment (Antony \& Mutalemwa, 2014; Lwoga \& Lwoga, 2017; Kalugendo, 2018). Perceived ease of use, perceived usefulness, perceived awareness, perceived benefits, and cost effects were used to influence mobile banking adoption (Abdinoor \& Mbamba, 2017). Furthermore, this also include the following: Perceived trust and ease of use in adoption of mobile marketing (Chille et al., 2021); perceived usefulness, perceived ease of use and compatibility (Lwoga \& Lwoga, 2017); and the relationship between mobile 
payment knowledge and perceived ease of use (Lwoga \& Lwoga, 2017). Another model that has been used is the Unified Theory of Acceptance of Technology (UTAUT) (Chachage et al., 2013; Tossy, 2014). However, these studies places emphasis on students' intention to use mobile payment (Chachage et al., 2013); mobile payment acceptance on Small and Medium Enterprises (SMEs) (Kalugendo, 2018); mobile banking (Abdnoor \& Mbamba, 2017); mobile payment (Lwoga \& Lwoga, 2017); and relationship between consumer personality, web design, and trust on consumer purchase of automobile using trust and signaling theories (Masele \& Malama, 2019). Nonetheless, there are scant studies which have been done in Tanzania on the effects of Perceived Usefulness (PU), Perceived Ease of Use (PEOU), and Perceived Customer Knowledge (PCK) on mobile marketing adoption especially in the telecommunication sector.

Since there are few studies on mobile marketing adoption, especially on the effects of perceived usefulness, perceived ease of use and perceived customer knowledge on customers' mobile marketing adoption especially in the telecommunication sector, most of the studies done are on the aspects of mobile payment and mobile banking (Lwoga \& Lwoga, 2017; Malamsha, 2019). Thus, their findings have indicated that there is still low adoption on mobile marketing platforms, which implies that there are scant studies on the holistic mobile marketing approaches as per definitions of the Mobile Marketing Association (MMA, 2009).

However, previous studies in both developed and developing countries have mixed results on the influence of perceived usefulness and perceived ease of use with mobile marketing. Some scholars found positive and significant relationships (Abdinoor \& Mbamba, 2017; Hamza \& Shan, 2014; Lwoga \& Lwoga, 2017; Suki \& Suki, 2011; Tobbin \& Kuwornu, 2011), while other scholars found insignificant relationships either on perceived usefulness or ease of use with mobile marketing adoption (Chinomona \& Sandala, 2013; Hu et al., 2019; Kim et al., 2010).

Past studies have also indicated mixed results on the effects of customer knowledge on technology adoption especially on the mobile marketing adoption. On one hand, some studies have indicated positive relationship between customer knowledge and mobile marketing adoption (Bosil \& Junhiack, 2009; Lwoga \& Lwoga, 2017; Obina \& Nkoe, 2016). On the other hand, other studies indicated non-significant effects between customer knowledge and mobile marketing adoption (Aydin \& Burnaz, 2016; Musa et al., 2016). However, these studies were mostly on ether mobile payment or mobile banking and not holistic mobile marketing as per the objectives under this study.

Nevertheless, there are few studies in telecommunication industry, specifically on customers' adoption of mobile marketing and relating it with 
perceived usefulness and perceived ease of use and perceived customer knowledge in telecommunication industry in Tanzania. Therefore, due to paucity of studies in the sector, there is a need to assess the influence of perceived usefulness, perceived ease of use, and perceived customer knowledge on mobile marketing adoption in the telecommunication industry in Tanzania.

There are various models and theories which have been used in describing the adoption and diffusion of technology. These are; Theory of Planned Behavior (TPB) (Ajzen, 2002), Theory of Reasoned Action (Khraim et al., 2011), Technology Organization Environment (TOE) (Pudjianto et al., 2011), Diffusion of Innovation Theory (DOI) (Rodgers, 2003), Technology Acceptance Model (TAM) (Venkatesh et al., 2016). Among these theories and models, TAM has been used in many studies because it highlights better adoption behavior of consumers in using technology (Ofori, 2019). The current study has revealed that there is a need of using TAM by combining it with DOI to increase the explanatory power of the model in predicting customers' adoption of mobile marketing in telecommunication industry in Tanzania. The major TAM constructs are Perceived Usefulness (PU) and Perceived Ease of Use (PEOU), which are behavioral components of the model, while other components of the model are Behavior Intention (BI) and Attitude (AT) as supporting components of PU and PEOU (Venkatesh et al., 2012).

However, Behavior Intention (BI) under TAM was dropped as previous studies have indicated that BI does not necessarily lead to the actual use of the system (Ajibade, 2018; Bagozzi, 2007; Taylor \& Todd, 1995). However, in his study, Davis et al. (1989) argued that attitude partially influence the perceived usefulness (PU) and perceived ease of use (PEOU) towards behavior intention (BI). Ren (2019) also argued that subjective norms manipulation affects only behavior intention (BI) and not attitude, and concluded that an attitude can remain the same to an individual regardless of the adoption and innovation process in new information technology. With those reasons therefore, attitude was also excluded as part of this study under TAM constructs. Therefore, this study attempts to design and develop "Integrative Adoption Model" by combining the Technology Acceptance Model (TAM) and Diffusion of Innovation Theory (DOI) by assessing the effects of PU, PEOU, and PCK in order to identify the factors that can influence customers' mobile marketing adoption in the telecommunication industry in Tanzania.

\section{Perceived Usefulness and the Adoption of Mobile Marketing}

Perceived Usefulness (PU) is the major construct of the Technology Acceptance Model (Davis, 1989) by which consumers can prefer a product 
when they think it useful to them. This in turn reinforces the consumer's intention to adopt the product or service (Kim et al., 2010). Many studies have indicated the use of perceived usefulness (PU) and perceived ease of use (PEOU) as major components of technology adoption.

Various studies have shown significant effects on PU and the adoption of mobile marketing (Abdinoo \& Mbamba, 2017; Hamza \& Shah, 2014; Mehra et al., 2020; Olubumni \& Adeyemi, 2018). Therefore, this study has proposed the hypothesis on the factors that influence customers' adoption of mobile marketing in telecommunication industry in Tanzania as follows:

H1: Perceived usefulness has significant and positive influence on customers' adoption of mobile marketing in the telecommunication industry.

\section{Perceived Ease of Use (PEOU) and the Adoption of Mobile Marketing}

Perceived Ease of Use (PEOU) refers to how a person feels in using the technology that s/he will be free from effort (Venkatesh et al., 2016). According to Venkatesh et al. (2016), consumers will always perceive ease to use the information system at an ealier stage when they experience using the proposed information system, in accordance with their beliefs on the information system products or services they are using.

Various studies have shown significant effects on PEOU and the adoption of mobile financial service (Chitungo \& Munongo, 2013; Hamza \& Shah, 2014; Kim et al., 2010; Said et al., 2019 ; Tobbins \& Kuwornu, 2011;Wamuyu, 2014), when consumers are using the mobile marketing products and services. In Tanzania, Lema (2017) indicated that perceived ease of use does not influence the adoption of mobile financial services for the unbanked population. However, Lwoga and Lwoga (2017) found that PEOU has influence on mobile payment. Also, Lubua and Semlambo (2017) indicated that PEOU has a significant influence on mobile payment in Small and Medium Enterprises (SMEs). Therefore, this study proposed the following hypothesis:

H2: Perceived ease of use has significant and positive influence on customers' adoption of mobile marketing in the telecommunication industry.

\section{Perceived Customer Knowledge (PCK) and the Adoption of Mobile Marketing}

Perceived customer knowledge refers to individual learning about innovation and thereafter finds information about innovation (Rodgers, 2003). Various studies have shown significant effects on Perceived Customer Knowledge and adoption of mobile financial service as part of mobile 
marketing (Bosil \& Junhjack, 2009; Obina \& Nkoe, 2016; Lwoga \& Lwoga, 2017), while the study by Aydin and Burnaz (2016) and Musa et al. (2016) indicated that customer knowledge has no influence on mobile marketing adoption by customers. Therefore, this study proposed the following hypothesis:

H3: Perceived customer knowledge has significant and positive influence on customers' adoption of mobile marketing in the telecommunication industry.

\section{Methodology}

The study was undertaken using primary data from mobile phone users from the five municipalities of Dar es Salaam, namely Ubungo, Kinondoni, Ilala, Kigamboni, and Temeke. The areas were chosen due to the large contribution of Dar es Salaam to the country's Gross Domestic Product (GDP), which accounts for 30\% in 2018 (Tanzania Invest, 2018). Out of 440 questionnaires, 406 were returned. The questionnaires collected information about respondent characteristics, Adoption of Mobile Marketing (AMM), Perceived Usefulness (PU), Perceived Ease of Use (PEOU), and Perceived Customer Knowledge (PCK). The population consisted of all customers of the three telecommunication companies namely Vodacom, Airtel and MIC (T) Limited (Tigo) in the 5 municipalities. Multistage sampling was applied in the selection of respondents who use mobile marketing platforms.

7-point Likert type scale was used ranging from 1 (Strongly disagree) to 7 (strongly agree). Perceived Usefulness (PU) was measured by five items, which were adapted from Davis (1989) and Gao et al. (2011). Perceived Ease of Use (PEOU) was measured by five items, adapted from Venkatesh et al. (2012) and Gao et al. (2011). Perceived customer knowledge was measured by 4 items adapted from Wang et al. (2009) and Kim et al. (2010), while the Adoption of Mobile Marketing (AMM) were measured by 7 items adopted from Davis (1989) and Duzevi et al. (2016).

\section{Results}

\section{Respondent Characteristics}

The sample characteristics under the study were the customers of the three telecommunication companies. First are the employees which included the respondents with formal employment and paid up salaries who had mobile phones, accounting for 128 (31.5\%) of the respondents. Second are business persons such as sales agents and wholesalers of consumers and industrial products who have mobile phones, accounting for $89(21.9 \%)$ of the respondents. Third are customers working in the informal sectors (not with formal employment) which were retailers of consumers and industrial products with mobile phones, accounting for $96(23.6 \%)$ and $93(22.9 \%)$ of 
them were students from tertiary education institutions. Since gender has an influence on technological adoption (Lwoga \& Lwoga, 2017), the gender of the respondents was analyzed. Out of 406 participants who returned the questionnaires, $203(50 \%)$ participants were females and $203(50 \%)$ were males.

\section{Reliability Test}

Reliability was tested to ascertain if the available research tools measures the intended outcomes (Saunders et al., 2012). Cronbach's alpha was used to measure the internal consistency of the research instruments. The results on the reliability on Cronbach's alpha ranged from 0.905 to 0.921 . Since all the values were above 0.7 , which is the cutoff point, this indicated that the questionnaire used was reliable in measuring the studied constructs (Saunders et al., 2012). Table 1 indicates the reliability results.

In order to assess if items measured the same construct, exploratory factor analysis was done. Before exploratory factor analysis, Kaiser Mayer Olkin (KMO) and Bartlett's Test for Sphericity (BTS) were tested for factor analysis suitability. Hence, it is argued that KMO should be greater than 0.6 and BTS values should be less than 0.05 of the significant level to indicate that Factor Analysis is suitable for the data (Basto \& Pereira, 2012). Since BTS had a value of less than 0.001 and KMO had a value of 0.8 , the data were suitable for FA.

According to Basto and Pereira (2012), for items which measure similar outcomes to have similarities, factor loading should have the cutoff point of above 0.3 such that the item with factor loading above 0.3 were retained for analysis. As indicated in Table 2, factor loading had value above 0.3 which is the cutoff point which indicated that items were reliable for the studied phenomenon and analysis.

Table 1.Summary of Reliability and Validity of Data

\begin{tabular}{|c|c|c|c|c|}
\hline \multirow[b]{2}{*}{ Construct } & \multirow{2}{*}{$\begin{array}{c}\text { Reliability } \\
\text { Cronbach's } \\
\text { alpha }\end{array}$} & \multicolumn{2}{|c|}{ 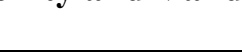 } & \multirow{2}{*}{$\frac{\text { BTS }}{X^{2}(P-V \text { alue })}$} \\
\hline & & $\begin{array}{l}\text { No. of } \\
\text { items }\end{array}$ & KMO & \\
\hline $\begin{array}{c}\text { Adoption of Mobile } \\
\text { Marketing }\end{array}$ & 0.921 & 7 & 0.915 & $1840.2(<0.001)$ \\
\hline Perceived Usefulness (PU) & 0.920 & 5 & 0.894 & $\begin{array}{l}1427.878 \\
(<0.001)\end{array}$ \\
\hline $\begin{array}{c}\text { Perceived Ease of Use } \\
\text { (PEOU) }\end{array}$ & 0.905 & 5 & 0.857 & $\begin{array}{l}1286.215 \\
(<0.001) \\
\end{array}$ \\
\hline $\begin{array}{l}\text { Perceived Customer's } \\
\text { Knowledge (PCK) }\end{array}$ & 0.899 & 4 & 0.842 & $970.949(<0.001)$ \\
\hline
\end{tabular}

Source: Fieldwork, (2020)

Where; 
KMO: Kaiser-Meyer-Olkin Measure of Sampling Adequacy

BTS: Bartlett's Test of Sphericity

Table 2. Factor Loading for each item under the studied constructs

\begin{tabular}{|c|c|c|}
\hline Construct & Item & Factor Loading \\
\hline Perceived Ease of Use & PEOU1 & 0.879 \\
\hline \multirow[t]{4}{*}{ (PEOU) } & PEOU2 & 0.855 \\
\hline & PEOU3 & 0.845 \\
\hline & PEOU4 & 0.838 \\
\hline & PEOU5 & 0.837 \\
\hline \multirow[t]{5}{*}{ Perceived Usefulness (PU) } & PU2 & 0.893 \\
\hline & PU4 & 0.890 \\
\hline & PU3 & 0.875 \\
\hline & PU1 & 0.862 \\
\hline & PU5 & 0.834 \\
\hline \multirow{4}{*}{$\begin{array}{l}\text { Perceived Customer Knowledge } \\
\text { (PCK) }\end{array}$} & PCK3 & 0.885 \\
\hline & PCK4 & 0.878 \\
\hline & PCK2 & 0.871 \\
\hline & $\overline{\mathrm{PCK} 1}$ & 0.869 \\
\hline \multirow[t]{7}{*}{$\begin{array}{l}\text { Adoption of Mobile Marketing } \\
\text { (AMM) }\end{array}$} & AMM1 & 0.837 \\
\hline & AMM2 & 0.819 \\
\hline & AMM3 & 0.831 \\
\hline & AMM4 & 0.8 \\
\hline & AMM5 & 0.794 \\
\hline & AMM6 & 0.836 \\
\hline & AMM7 & 0.842 \\
\hline
\end{tabular}

Source; Fieldwork (2020)

Extraction Method: Principal Component Analysis

Rotation Method: Varimax with Kaiser Normalization

Only one component was extracted per each construct from its related variables.

The solution was not rotated (No rotated component matrix)

\section{Correlation Analysis}


Correlation Analysis was undertaken to establish the relation between the variables. According to Senthilnathan (2019), correlations ranging from +0.00 to +-0.30 shows little correlation, +-0.30 to +-0.50 shows low correlation, $+-0,50$ to +-0.70 moderate, -+0.70 to +-0.90 high, and -+0.90 to 1.00 extremely high correlation. Multicollinearity is possible in the model when $r>=+-0.9$ (Senthilnathan, 2019). The correlation in Table 3 indicates that correlation between independent variables and dependent variables ranges from $r=0.550$ to $r=0.707$ at $p<0.01$. This shows that all independent variables have significant relationship with Adoption of Mobile Marketing (AMM) in the Tanzania telecommunication industry.

Table 3. Inter- Correlation among Variables $(\mathrm{N}=406)$

\begin{tabular}{|c|c|c|c|c|}
\hline Variable & AMM & PU & PEOU & PCK \\
\hline AMM & 1 & $0.692^{* *}$ & $0.568^{* *}$ & $0.550^{* *}$ \\
\hline PU & $0.692^{* *}$ & 1 & $0.707^{* *}$ & $0.787^{* *}$ \\
\hline PEOU & $0.568^{* *}$ & $0.707^{* *}$ & 1 & $0.597^{* *}$ \\
\hline PCK & $0.550^{* *}$ & $0.787^{* *}$ & $0.597^{* *}$ & 1 \\
\hline N & 406 & 406 & 406 & 406 \\
\hline
\end{tabular}

**Correlation is significant at the 0.01 level (2-tailed); Source; Fieldwork, (2020)

\section{Multiple Linear Regression Analysis}

Multiple linear regression analysis was undertaken in order to test the hypothesis of the studied objectives. As indicated in Table 4.5, the fitness of the model used was analyzed based on the analysis and indicated the $\mathrm{F}$ statistics to be $\mathrm{F}=186.04$, which was significant at $\mathrm{p}<0.001$. Thus, this indicated the model was fit on the studied phenomenon and that all variables explained the adoption of mobile marketing. The coefficient of determination (R squared) was 0.699 and the adjusted $\mathrm{R}$ was 0.696 , which indicated that all variables showed 70 percent on the adoption of mobile marketing.

Furthermore, model residuals were independent as the Durbin Watson statistic was closer to 2. The data obtained had value less than 1 . Hence, no evidence of outliers was found. According to Daoud (2018) for absence of multicollinearity, VIF should range between 1 to 5 and the Tolerance should range from 0 to 1 . This indicates the absence of multicollinearity on the model as indicated in Table 4. 
Table 4. Overall Linear Regression Assumptions and Model Summary

\begin{tabular}{|c|c|c|c|c|c|c|c|c|c|c|}
\hline \multirow[t]{2}{*}{ Model } & \multicolumn{2}{|c|}{$\begin{array}{l}\text { Unstandardized } \\
\text { Coefficients }\end{array}$} & \multirow{2}{*}{$\begin{array}{l}\text { Standardized } \\
\text { Coefficients } \\
\text { Beta }\end{array}$} & \multirow{2}{*}{$\mathrm{t}$} & \multirow[t]{2}{*}{$\operatorname{Sig}(P)}$. & \multicolumn{2}{|c|}{$\begin{array}{l}95.0 \% \text { Confidence } \\
\text { Interval for B }\end{array}$} & \multirow{2}{*}{$\begin{array}{l}\text { Correla } \\
\text { tion } \\
\text { Partial }\end{array}$} & \multirow[b]{2}{*}{$\begin{array}{l}\text { Toler } \\
\text { ance }\end{array}$} & \multirow[b]{2}{*}{ VIF } \\
\hline & B & Std. Error & & & & $\begin{array}{l}\text { Lower } \\
\text { Bound }\end{array}$ & $\begin{array}{l}\text { Upper } \\
\text { Bound }\end{array}$ & & & \\
\hline PU & 0.792 & 0.030 & 0.357 & 6.784 & $(<0.001)$ & 0.253 & 0.46 & 0.321 & 0.272 & 3.681 \\
\hline PEOU & 0.768 & 0.056 & 0.19 & 3.31 & 0.001 & 0.077 & 0.303 & 0.163 & 0.229 & 4.376 \\
\hline PCK & 0.750 & 0.33 & 0.12 & 2.07 & 0.039 & 0.006 & 0.233 & 0.103 & 0.226 & 4.429 \\
\hline $\mathrm{R}$ & 0.795 & R squared & Adjusted R & $\begin{array}{l}\text { Std error } \\
\text { of } \\
\text { estimate }\end{array}$ & $\begin{array}{l}\text { Dublin } \\
\text { Watson }\end{array}$ & $\mathrm{F}$ & $\begin{array}{l}\text { Sign } \\
\text { value })\end{array}$ & & & \\
\hline & & 0.699 & 0.696 & $0 . .55$ & 1.783 & 186.04 & $(<0.001)$ & & & \\
\hline
\end{tabular}

Source; Field work, 2020

\section{Effect of Perceived Usefulness (PU) on AMM}

The findings from Table 4 indicated that Perceived Usefulness (PU) has significant effects on the adoption of mobile marketing as there was a significant positive association as one scale increase in PU resulted into a 0.36 (95\% CI: $0.253,0.46)$ increase in AMM at $p<0.001$. Therefore, the alternative hypothesis that Perceived usefulness significantly influences adoption of mobile marketing is supported and the null hypothesis is rejected.

\section{Effect of Perceived Ease of Use (PEOU) on AMM}

The findings from Table 4 indicated that Perceived Ease of Use (PEOU) has significant effects on the adoption of mobile marketing at $0.19(95 \% \mathrm{CI}$; $0.077,0.303)$ at $\mathrm{P}=0.001$. Therefore, the alternative hypothesis is supported that Perceived Ease of Use (PEOU) significantly influences adoption of mobile marketing, while the null hypothesis is rejected.

\section{Effect of Perceived Customer Knowledge (PCK) on AMM}

The findings from Table 4 indicated that Perceived Customer Knowledge (PCK) has significant effects on the adoption of mobile marketing $(95 \% \mathrm{CI}$; $0.006,0.233$ ) at $\mathrm{P}=0.039$. Therefore, the alternative hypothesis is supported 
that Perceived Ease of Use (PEOU) significantly influences adoption of mobile marketing, while the null hypothesis is rejected.

\section{Discussion}

The findings have established the significance of mobile marketing for the researchers and practitioners concerning the adoption of mobile marketing in telecommunication industry. The findings have indicated that perceived usefulness positively influences adoption of mobile marketing. This implies that mobile service providers and researchers should attach the need of consumer usefulness on the mobile marketing products and services as it was noted that customers in the telecommunication industry in Tanzania are prone to the usefulness of the mobile marketing platforms which can reduce the customer's problems.

Consequently, the findings are consistent with the study done by Abdinoo and Mbamba (2017), Hamza and Shah (2014), Mehra et al. (2020), and Olubumni and Adeyemi (2018). Thus, they indicated that perceived usefulness is significant in influencing mobile marketing adoption. In theoretical understanding, these findings give important knowledge on the important factors in customers' adoption of mobile marketing products in telecommunication industry in Tanzania, particularly the importance of perceived usefulness as the important determinants of consumers' adoption of mobile marketing products and services. The findings are consistent with the Technology Acceptance Model (TAM) that PU influences consumers' adoption of technology.

Regarding the findings on Perceived Ease of Use (PEOU), results indicate that it has significant effects on the adoption of mobile marketing in the telecommunication industry in Tanzania. These findings are consistent with the studies done by Chitungo and Munongo (2013), Hamza and Shah (2014), Kim et al. (2010), Said et al. (2019), Tobbins and Kuwornu (2011) that PEOU significantly influence adoption of mobile financial services. As Lwoga and Lwoga (2017) insisted that mobile marketing is still in its infant stages in Tanzania, mobile marketing service providers should ensure that their products are easily accessed by customers and that they are easy and simple to use. This will facilitate more adoption of mobile marketing platforms.

The findings are not consistent with the study done by Chinomona and Sandala (2013) in South Africa; Hu et al. (2019) in China; Kocukusta et al. (2015) in Hongkong, which found insignificant relationships between perceived ease of use with mobile marketing adoption. These could be attributed to the contextual factors that customer preferences and adoption of 
mobile marketing products are influenced by the culture, environmental factors, lifestyles, and demand patterns (Wamuyu, 2014). The important findings on this study entails that mobile marketing strategies by the mobile marketing service providers need to ascertain the demographic differences of their customers before designing and selling their mobile marketing technology in the market.

In theoretical understanding, these findings give out the important factors in customers' adoption of mobile marketing products, particularly the importance of perceived ease of use, as the important determinants of consumers' adoption of mobile marketing products and services in the telecommunication industry in Tanzania. The findings are consistent with the Technology Acceptance Model (TAM) that PEOU influences consumers' adoption of technology.

The study has adopted the Technology Acceptance Model by the use of two main constructs which are Perceived Usefulness and Perceived Ease of Use in the context of assessing the factors influencing customers' adoption of mobile marketing in telecommunication industry in Tanzania. However, the study extended the TAM and included Perceived Customer Knowledge (PCK) which was guided by the Diffusion of Innovation Theory (DOI). It also indicated the importance of customers' knowledge of mobile marketing platforms before adoption (Acheampong et al. 2019). This indicates that the customers in the telecommunication industry in Tanzania will find the mobile marketing platform useful and easy to use when combined with the customer's understanding of the mobile marketing products and services. Therefore, mobile service providers in the telecommunication industry in Tanzania should emphasize the need for promotion of the mobile marketing products and services, by giving customers knowledge on mobile products, in order to entice more customers to adopt the mobile marketing technology.

\section{Conclusion}

The objective of the study was to identify the factors affecting the adoption of mobile marketing in telecommunication industry in Tanzania by assessing the effects of perceived usefulness, perceived ease of use, and perceived customer knowledge. The overall findings of this study conform to the Technology Acceptance Model (TAM) in assessing the effects of perceived usefulness and perceived ease of use on adoption of mobile marketing in Tanzania. Therefore, this shows a positive influence on the adoption of mobile marketing in Tanzania. The integrated theoretical framework from TAM and DOI constructs of PU, PEOU, and PCK show a significant influence on customers' adoption in telecommunication industry 
in Tanzania. In addition, the integrated theoretical framework has indicated the parsimonious contribution in predicting the adoption of mobile marketing in Tanzania by using fewer variables of perceived usefulness, perceived ease of use, and perceived customer knowledge which have showed high explanatory power on the study findings in explaining the adoption of mobile marketing. Empirically, it can be concluded that mobile service practitioners need to develop mobile platforms and applications that are easy and useful on the consumers' perspectives and which are easily understood based on its benefits by the customers.

\section{Study Recommendations}

In theoretical underpinning of the study, the construct of perceived usefulness and perceived ease of use were part of Technology Acceptance Model (TAM), whereas Perceived Customer Knowledge construct was part of Diffusion of Innovation Theory (DOI), which provided significant understanding of the customer's adoption of mobile marketing in telecommunication industry in Tanzania. It has revealed that customers perceive positive adoption on mobile marketing platforms and accept those platforms that are easy to use and useful. Hence, they need to understand the mobile products and services offered in order to adopt. Also, consumers should assess the mobile marketing products depending on how the system is useful and easy to use.

Mobile service providers and researchers need to understand their customers' benefits on the mobile marketing products. This is because customers are focused on usefulness and ease of use on the products or services, which have been indicated as important components of customers' benefits. In addition, service providers (practitioners) need to improve their marketing and business strategies in relation with understanding the consumers' demands, markets, and types of products with the reflection of understanding of customers' benefits (Asiedu \& Sarfo, 2013). Kotler and Keller (2012) opined that the consumers' preference on products or service is the core benefit of the product a consumer is looking for. This will imply that mobile service providers ought to improve the performance of the mobile marketing systems and programs over time, and also undertake thoroughly marketing research that will stimulate customers' benefits in terms of usefulness and ease of use of mobile marketing products (Kumar et al., 2018). This will trigger much adoption for the better business growth of the telecommunication sector. This could be attained by proper segmenting of the customers, by understanding the needs of products in terms of usefulness and ease of use to them.

Subsequently, these findings revealed that customers need products that are easy to use. Most designers in the information system often think of 
designing products that are useful and of ease of use to the customers. However, it should be understood that usefulness and ease of use is important but not sufficient (Venkatesh et al., 2012). Furthermore, it should be understood that customers need products that are easily understood by them. Therefore, mobile service providers need to understand their customers' needs and demands, and influence the consumers' interests, by explaining the benefits of their products and services in order to offer more differentiated products that conform to the customers' knowledge (Kwamboka et al., 2018).

Mobile service stakeholders and government should work hand-inhand in formulating better policies that can assist mobile service providers to sell more on mobile products and services that meet the demands of the customers. This calls for the mobile service stakeholders' improvement by having better technology infrastructure, which goes with the support of reduction in tax by the government to stimulate customers' demand. Thus, this will enhance the economy of the country and the growth of the telecommunication business in Tanzania.

\section{Areas for Further Study}

This study used the TAM constructs of Perceived Usefulness and Perceived Ease of Use and added the new construct of Perceived Customer Knowledge from the Diffusion of Innovation Theory (DOI). The combined model, therefore, can be used in future studies in other sectors such as banking, manufacturing, and tourism for further understanding of the factors influencing customers' adoption of mobile marketing in Tanzania and other developing countries.

There are a lot of factors which have not been undertaken in this study, and further studies regarding the adoption of mobile marketing in Tanzania need to be done. The fact that the study was done only in one region out of the 26 regions of Tanzania, could mean that the sample may sometimes not be the actual representation of the entire population regarding mobile marketing adoption in Tanzania. However, this study was limited to Perceived Ease of Use, Perceived Usefulness, and Perceived Customer Knowledge. Further study may include other factors such as perceived enjoyment, perceived risks, attitude, compatibility, system characteristics, and perceived behavioural intention in understanding the factors influencing the customer's adoption of mobile marketing in telecommunication industry in Tanzania. 


\section{References:}

Abdinoor, A. \& Mbamba, U. O. L. (2017). Factors influencing consumers' adoption of mobile financial services in Tanzania. Cogent Business and Management, 4(1). 3-5

Acheampong, S., Kankam-Kwarteng, C., \& Donkor, J. (2019). Customer perceived risks and the choice of mobile phone brand in Ghana. European Scientific Journal, ESJ, 15(7), 239. https://doi.org/10.19044/esj.2019.v15n7p23

Ajibade, P. (2018). Technology acceptance model limitations and criticisms: Exploring the practical applications and use in technology-related studies, mixed-method, and qualitative researches.Retrieved July,18, 2020, from https;// www. Researchgate.net.

Ajzen, I. (2002). Perceived behavioral control, self efficacy, locus of control, and the theory of planned behavior. Journal of Applied Social Psychology. 32(4), 665-683.

Antony, D., \& Mutalemwa, D.K. (2014). Factors influencing the use of mobile payments in Tanzania. Insights from Zantel's Z-pesa Services. Journal of Language, Technology and Entrepreneurship in Africa,5(2),69-90.

Asa, A. U., \& Uwem., C. A. (2017). Utilization of Mobile Phones for Agricultural Purposes by Farmers in Itu Area, Nigeria. European Scientific Journal, ESJ, 13(19), 395. https://doi.org/10.19044/esj.2017.v13n19p395

Asiedu, M., \& Sarfo, J. O. (2013). A multi-dimensional service delivery among mobile network providers in Ghana: a case of customer satisfaction. European Scientific Journal, ESJ, 9(23). https://doi.org/10.19044/esj.2013.v9n23p\%

Aydin, G., \& Burnaz, S. (2016). Adoption of mobile payment system; A study on mobile wallets. The case of Turkey. Journal of Business Economics and Finance, 5(1),435-564

Bagozzi, R. P. (2007). The legacy of technology acceptance model and proposal for paradigm shift. Journal of the Association of Information System, 8, 244-254.

Barutcu, S., Yaldir, A., \& Hasiloglu, S. B. (2017). From Mass to Personalized Mobile Marketing Strategies: The New Dimensions Through Expert Systems. European Scientific Journal, ESJ, 13(10). https://doi.org/10.19044/esj.2017.v13n10p\%p

Basto, M. \& Pereira (2012). An SPSS- menu for ordinal factor analysis. Journal of Statistical Software, 46(4), 1-29

Bosil, D., \& Jurijak, I. (2009). The role of knowledge management in innovation. Journal of Journal of Knowledge Management, 11(4),20-29

Chachage, B., Kamuzora, F., \& Malima, G. (2013). Factors influencing acceptance of mobile money Services amongst students of higher learning institutions in Tanzania with special referenece to Ruaha University College. International Journal of Management,2(2),9-18.

Chille, F., Shayo, F., \& Nasra, K. (2021).The Effects of perceived trust and ease of use in adoption of mobile marketing in telecomunication industry in Tanzania. 
American Scientific Research Journal for Engineering, Technology, and Sciences (ASRJETS), 76(1), 155-168

Chinomona, R., \& Sandala, V. (2013). The influence of market related mobile activities on the acceptance of mobile marketing and consumers intention to purchase promoted by SMS in South Africa.The Jounrnal of Applied Research, 29(3).1899-1909

Chitungo, S. K., \& Munongo, S. (2013). Extending the technology acceptance model to mobile banking adoption in rural Zimbabwe. Journal of Busines Administration and Education, 3(1), 51-79.

Dahiya, R. \& Gayatri, G. (2018). A research paper on digital marketing communication and consumer buying decision process: an empirical study in the indian passenger car market. Journal of Global Marketing, 31(2), 73-95.

Daoud, J. I. (2018). Multicollinearity and regression analysis. Journal of Physics: Conference Series, 949(1).

Davis, F. D., Bagozzi, R., P., \& Warshaw, P. R. (1989). User Acceptance of computer technology. A Comparison of two theoretical models. Management Science, 35,982-1003

Dužević, I., Delić, M., \& Knežević, B. (2016). Customer satisfaction and loyalty factors of Mobile Commerce among young retail customers in Croatia. Gestão E Sociedade, 10(27), 1476.

Eze, S. C., Chinedu-Eze, V. C. A., Okike, C. K., \& Bello, A. O. (2020). Critical factors influencing the adoption of digital marketing devices by serviceoriented micro-businesses in Nigeria: A thematic analysis approach. Humanities and Social Sciences Communications, 7(1). https://doi.org/10.1057/s41599-020-00580-1

Gao, S., Krogstie, J., \& Siau, K. (2011). Developing an instrument to measure the adoption of mobile services. Mobile Information Systems, 7(1), 45-67.

Hall, J. (2018). Mobile Marketing strategy.Retrieved march,13, 2019, from htpp;//www.biznessapp. com/wp-content/uploads.

Hamza, A., \& Shah, A. (2014). Gender and mobile payment system adoption among students of tertiary institutions in Nigeria. International Journal of Computer and Information Technology.3(1),13-20

Hu, Z., Ding, S., Li, S., Chen, L., \& Yang, S. (2019). Adoption intention of fintech services for bank users: an empirical examination with an extended Technology Acceptance Model. Symmetry,1(3), 340

Jauhari, V., \& Dutta, K. (2010). Services Marketing, Operations, and Management (3th ed). Oxford University Press,

Kalugendo, E. J. (2018). The Influence of Mobile Money Services Usage on Small and Medium Enterprises in Tanzania (Doctoral Thesis). Open University of Tanzania.

Keung. J., Jeffery, B., \& Kitchenham,B(2004).The Challenge of Introducing a new software cost estimation technology into a small software organization. Proceedings of the 2004. Australia Software Enginnering Conference(ASWECO4), IEEE Computer Society Press, 52-59. 
Khraim, H. S., Shoubaki, Y. E. A. L., \& Khraim, A. S. (2011). Factors affecting Jordanian consumers' adoption of mobile banking services. International Journal of Business Social Science, 2(20), 96 -105.

Kim, C., Mirusmonov, M., \& Lee, H. G. (2010). An empirical examinatio $\mathrm{n}$ of factors influencing the intention to use mobile payment. Computers in Human behaviour, 26(3),311-324.

Kotler, P., \& Keller, K.L. (2012). Marketing Management (14th ed). Prentice Hall, Kucukusta, D., Lau, R., Besbes, A. \& Legoherel, P. (2015). Reexamining perceived usefulness and perceived ease of use on online booking. International Journal of Contemporary Hospitality Management, (27)2, 185-198.

Kumar, V., Leone, R. P., Aaker, D.A., \& Day, G.S. (2018). Marketing Research(13 ${ }^{\text {th }}$ ed),Wileys Publications

Kwamboka, M. J., Sulo, T., \& Korir, M. (2018). The moderating effect of brand architecture on the relationship between tangibility and customer loyalty among telephone mobile subscribers in Kenya. European Scientific Journal, ESJ, 14(15), 298. https://doi.org/10.19044/esj.2018.v14n15p298Lamptey, H. K. (2018). Mobile commerce in developing countries: An evaluation of selected articles. Science and Technology, 8(1), 17-26. https://doi.org/10.5923/j.scit.20180801.03

Lema, A. (2017). Factors influencing the adoption of mobile financial services in the Ubnaked population. Journal of Humanities and Social Sciences, 9(1),3749

Lwoga, E. T., \& Lwoga, N. B. (2017). User acceptance of mobile payment: The effects of user-centric security, system characteristics Lubua and gender. Electronic Journal of Information Systems in Developing Countries, 81(1), 124..https://doi.org/10.1002/j.1681-4835.2017.tb00595.x

Malamsha, K. C. (2019). Adoption of mobile banking services by mobilephone owners in Moshi. Proceedings of Economics and Finance Conferences 8911512, International Institute of Social and Economic Sciences.

Masamila, B. (2014). State of mobile banking in Tanzania and security issues. International Journal of Network Security \& Its Applications, 6(4), 53-64.

Mansour, B.K. (2016). An analysis of business' acceptance of internet banking: an integration of e-trust to the TAM. Journal of Business and Industrial Marketing, 31(8), 982-994. https://doi.org/10.1108/JBIM-10-2016-271

Masele, J. J., \& Matama, R. (2019). Individual consumers' trust in B2C automobile e-commerce in Tanzania: Assessment of the influence of web design and consumer personality. Electronic Journal of Information Systems in Developing Countries, 86(1). https://doi.org/10.1002/isd2.12115

Mehra, A., Paul, J. \& Pratap, R. (2020). Determinats of mobile apps adoption among young adults; theoretical extension analysis. Journal of Marketing Communications, 1-29. https;//doi.org/10.1080/135766. 2020.1725780

MMA (2009). Mobile Marketing definition .Retrived on January,15,2017 from https://www.mmaglobal.com/news/mma-updates-definition-mobilemarketing\#: :text= 
Mtebe, J. S., \& Raisamo, R. (2014). Investigating students behaviour intention to adopt and use mobile learning in higher education in East Africa. The International Journal of Education and Development using Information and Communication Technology(IJEDICT).10(2),4-20

Musa, H., Li, S. C. H., Abas, Z. A., \& Mohamad, N. (2016b). Factors influencing the adoption of mobile marketing in small and medium enterprises (SMEs) in Malaysia..International Soft Science Conference (ISSC 2006). The European Proceedings of Social and Behavioral Sciences(EpSBS), 457-463.

Mwantimwa, K. (2019). ICT usage to enhance firms' business processes in Tanzania. Journal of Global Entrepreneurship Research. 9(1). https://doi.org/ 10.1186/ s40497-019-0170-6

Obina \& Nkoe (2016). Determinants of customers brand choice and contiuance intention on mobilephone adoption among Students in Southern East Nigeria. International Journal of Computer and Information Technology.5(2),17-25.

Ofori, E. (2019). Using technology acceptance model to promote students adoption and use of digital technology in the Sunyani Technical University. Journal of Basic and Applied Research International, 25(3), 1-13..Retrieved july 2020 from https://www.researchgate.net/publication/333758846.

Olubunmi, O. F. (2018). Determinants of continuance intention to use online shops in Nigeria. Journal of Internet Banking and Commerce, 23(2),54-57.

Ren, M. (2019). Why technology adoption succeeds or fails;an exploratory from the perspective of intra-organization legitimacy. The Journal of Chinese Sociology, 6(21),22-26.

Rodgers, E. M. (2003). Diffussion of Innovation( $\left.5^{\text {th }} e d\right)$..Newyork. Free Press.

Saaksjarvi, M. (2003). Consumer adoption of technology innovations. European Journal of Innovation Management,6(2),90-100.

Said, H. B. M., Izharuddin, A. F. Bin, Idris, I. B., \& Othman, H. B. (2019). Examining the relationships between perceived usefulness, perceived ease of use, enjoyment and self-efficacy on employees behavioral intention towards adopting online technology application at workplace: A case in Malaysia. American Journal of Social Sciences and Humanities, 3(1), 29-39. https://doi.org/10.20448/801.31.29.39

Saunders, M., Lewis, P., \& Thornhilll, A. (2012). Research Methods for Business Students ( $2^{\text {nd }}$ ed), Harlow, Pearson Education Ltd.

Senthilnathan, S. (2019). Usefulness of correlation analysis. SSRN Electronic Journal. https://doi.org/10.2139/ssrn.3416918.

Ström, R., Vendel, M., \& Bredican, J. (2014). Journal of retailing and consumer services mobile marketing: A literature review on its value for consumers and retailers. Journal of Retailing and Consumer Services, 21(6), 1001-1012. https://doi.org/10.1016/j.jretconser.2013.12.003

URT (2018). Quaterly Report Statistics Tanzania Communication Regulatory Authority(2018).

Venkatesh, V., Thong, J. Y., \& Xu, X. (2012). Consumer acceptance and use of information technology. Extending the unified theory of acceptance and use of technology. MIS Quarterly, 36(1), 157-178. 
Venkatesh, V., Davis, F. D., Venkatesh, V., \& Davis, F. D. (2016). A theoretical extension of the technology acceptance model. Four Longitudinal Field Studies. 46(2), 186-204.

Wamuyu, P.K. (2014). The role of contextual factors in the uptake and continuance of mobile money usage in Kenya. Electronic Journal of Information Systems in Developing Countries, 64(1), 1-19. https://doi.org/10.1002/j.16814835.2014.tb00457.x

Wilson, V. \& Mbamba, U. (2017). Acceptance of mobile phone payments in Tanzania: Technology acceptance model approach. Business Management Review, (20)2, 15-25 